\title{
Dry vs. wet: Properties and performance of collagen films. Part I. Mechanical behaviour and strain-rate effect
}

\author{
Shirsha Bose ${ }^{\mathrm{a}}$, Simin $\mathrm{Li}^{\mathrm{a}}$, Elisa Mele ${ }^{\mathrm{b}}$, Vadim V. Silberschmidt ${ }^{\mathrm{a},{ }^{*}}$ \\ ${ }^{\mathrm{a}}$ Wolfson School of Mechanical, Electrical and Manufacturing Engineering, Loughborough University, Loughborough, Leicestershire, LE11 3TU, UK ${ }^{\mathrm{b}}$ \\ Department of Materials, Loughborough University, Loughborough, Leicestershire, LE113TU, UK
}

A B S T R A C T

\begin{abstract}
Collagen forms one-third of the body proteome and has emerged as an important biomaterial for tissue engineering and wound healing. Collagen films are used in tissue regeneration, wound treatment, dural substitute etc. as well as in flexible electronics. Thus, the mechanical behaviour of collagen should be studied under different environmental conditions and strain rates relevant for potential applications. This study's aim is to assess the mechanical behaviour of collagen films under different environmental conditions (hydration, submersion and physiological temperature $\left(37^{\circ} \mathrm{C}\right)$ ) and strain rates. The combination of all three environment factors (hydration, submersion and physiological temperature $\left(37^{\circ} \mathrm{C}\right)$ ) resulted in a drop of tensile strength of the collagen film by some $90 \%$ compared to that of dry samples, while the strain at failure increased to about $145 \%$. For the first time, collagen films were subjected to different strain rates ranging from quasi-static $\left(0.0001 \mathrm{~s}^{-1}\right)$ to intermediate $\left(0.001 \mathrm{~s}^{-1}, 0.01 \mathrm{~s}^{-1}\right)$ to dynamic $\left(0.1 \mathrm{~s}^{-1}, 1 \mathrm{~s}^{-1}\right)$ conditions, with the strain-rate-sensitivity exponent $(\mathrm{m})$ reported. It was found that collagen exhibited a strain-rate-sensitive hardening behaviour with increasing strain rate. The exponent $m$ ranged from $0.02-0.2$, with a tendency to approach zero at intermediate strain rate 0.01 $\mathrm{s}^{-1}$ ), indicating that collagen may be strain-rate insensitive in this regime. From the identification of hyperelastic parameter of collagen film, it was found that the Ogden Model provides realistic results for future simulations.
\end{abstract}

\author{
Keywords: \\ Collagen \\ Environmental conditions \\ Tangent modulus \\ Hyperelastic models \\ Strain-rate sensitivity
}

\section{Introduction}

Collagen is one of the most important biological polymers, constituting one-third of the whole-body proteome, providing structural stability, elasticity and strength to tendons, ligaments, skin, cornea, bones, muscle etc. (Fratzl, 2008; Kadler et al., 2007). Collagen possess a very complex hierarchical order, with triple-helix collagen molecules being the lowest in its hierarchy (Hulmes et al., 1995; Orgel et al., 2006; Gautieri et al., 2011). These collagen molecules are in turn made up of amino acid strands, with each of these strands being a left-handed $\alpha$-helix with approximately $0.87 \mathrm{~nm}$ per turn (Tanaka et al., 1988; Ackerman et al., 1999). The triple-helix structure has a right-handed twist, with a period of $8.6 \mathrm{~nm}$. The collagen molecules (known as tropocollagen) has a length of $300 \mathrm{~nm}$ and a diameter of $1.5 \mathrm{~nm}$ (Nimni et al., 1988), organised in a staggered configuration. This length is known to affect the deformation behaviour of collagen at nanoscale due to the intermolecular shear or rupture of covalent bonds (Buehler, 2006). The arrangement of these collagen molecules form a periodic structure, known as the $D$-band, where $D=67 \mathrm{~nm}$ (Fratzl et al., 1998), with alternating overlap and gap regions of $0.46 \mathrm{D}$ and $0.54 \mathrm{D}$ (Sherman et al., 2015), respectively (Petruska and Hodge, 1964). Five collagen molecules staggered next to each other in parallel conformation form the next level of hierarchy - the collagen fibrils. Collagen fibrils have a diameter ranging between 100-500 nm (Moeller et al., 1995), whereas their length varies up to several millimetres. The collagen fibrils bundle up together to form the next level of hierarchy, the collagen fibres.

Films prepared from collagen solutions or dispersions find application in scaffolds for tissue regeneration (corneal and wound healing), devices for sustained release of hormones, dural substitutes, etc. (Collins et al., 1991; Maeda et al., 2001; Ber et al., 2005; Sang et al., 2017; Li et al., 2019; Liu et al., 2012, 2014). Recently, collagen films were also used in flexible electronics too (Moreno et al., 2015; Ghosh and Mandal, 2017) thanks to their flexibility, biocompatibility, biodegradability and piezoelectric behaviour (Fukada and Yasuda, 1964; Denning et al., 2014). The complex hierarchical structure of collagen affects mechanical response of collagen films, which, depending on specific biomedical applications can be subjected to different environmental and loading conditions.

\footnotetext{
* Corresponding author.

E-mail address: v.silberschmidt@1boro.ac.uk (V.V. Silberschmidt).
} 
Thus, the mechanical behaviour of collagen films was investigated not only at ambient conditions but also in hydrated or submerged conditions at physiological temperature (PT, $\left.37{ }^{\circ} \mathrm{C}\right)$. Collagen films were reported to exhibit elastic-plastic-strain hardening behaviour (Sionkowska et al., 2006; Moreno et al., 2015; Steele et al., 2013) at ambient state (it will be referred as dry in this paper), while $J$-stress-strain shape curves are typical of films in hydrated state (referred as wet) (Falini et al., 2004; Steele et al., 2013). Collagen films tested in dry or wet states do not necessarily replicate the in-vivo mechanical response of the material. Such a response can be generated in experiments conducted in aqua (i.e. submerged conditions) at physiological temperature (PT) 37 ${ }^{\circ} \mathrm{C}$. Wang et al. (2015) reported a drop of about $50 \%$ of tensile strength in wet state with respect to the dry one, with a significant increase in the failure strain. Wet collagen-cellulose composite thin films exhibited an increased elongation of $70-90 \%$ compared to dry ones, which was compromised by a decrease in tensile strength (Steele et al., 2013). Very few studies (Vrana et al., 2007; Grover et al., 2012) were carried out in submerged conditions (at RT), partially mimicking the in-vivo conditions. Bio-polymers are generally sensitive to temperature, and a slight increase in temperature can affect their mechanical behaviour (Torres et al., 2013; Kiss et al., 2009; Zhou et al., 2016). However, there was limited investigation on the mechanical properties of uncrosslinked (or pure) collagen films in submerged condition at RT or at PT (refer Table 1).

Hence, the study on the mechanical behaviour of uncrosslinked collagen films would provide a wider platform for design and fabrication of collagen-based (composite) films for the next generation of biomedical applications. Furthermore, combining the stress-strain results obtained from different environmental loading conditions with different hyperelastic material models, would generate hyperelastic material constants (for pure collagen) for applications in future simulations.

In addition, an investigation on the strain-rate-dependent behaviour of collagen film ranging from quasi-static to dynamic test conditions is essential considering that the mechanical response of biomaterials and biological tissues is often strain-rate dependent. Collagenous tissues such as tendons (Clemmer et al., 2010; Edwards et al., 2019), ligaments
(Bonner et al., 2015; Karunaratne et al., 2018), skin (Ottenio et al., 2015; Pissarenko et al., 2019) were previously reported to exhibit strain-rate-dependent behaviours. Such behaviour are strongly affected by the hierarchy of collagen (Bonner et al., 2015) and, at higher strain rates, the reduction of molecular strain and fibrillar gaps, which contribute to the debonding at the matrix-fibril interface Karunaratne et al. (2018). The investigations of Ottenio et al. (2015) and Pissarenko et al. (2019) also found strain-rate-dependent mechanical properties of human and pig skin, respectively. Hence, considering the potential applications of collagen films at different physiological loading rates, it would be of interest to investigate their strain-rate-dependent behaviour.

Part I of the paper analyses the mechanical behaviour of pure collagen in different environmental conditions and to study the effect of strain rate, ranging from quasi-static to dynamic loading conditions; while, the Part II focus on inelastic deformation and time-dependent behaviour of collagen films (Bose et al., 2020). In Part I, all the experiments are tested in tension to failure and different mechanical parameters are evaluated. The study was divided into three major parts: (a) assessment of the isotropic behaviour of the collagen film; (b) investigation of the mechanical response of collagen subjected to different environmental conditions; (c) establishing the effect of strain rates. Also, parameter indentification of hyperelastic behaviour was carried out in Abaqus Simulia to generate material parameters useful for numerical simulations. This investigation provides a foundation for the use of mechanical properties for simulation-based assessments of collagen-based biomedical devices to support their design and optimisation.

\section{Materials and methods}

\subsection{Materials}

Collagen Type I (Bovine Achilles Tendon) obtained from SigmaAldrich (St. Louis, USA), was stored at $2-6{ }^{\circ} \mathrm{C}$ and used without further modifications. Acetic acid (ACS reagent, $\geq 99.8 \%$ ) was also

Table 1

Different conditions of uniaxial tensile test for collagen-based films ( $\sigma_{\mathrm{UTS}}$ - ultimate tensile strength; $\boldsymbol{\varepsilon}_{\mathrm{UTS}}$ - ultimate tensile strain at failure).

\begin{tabular}{|c|c|c|c|c|c|c|c|c|}
\hline \multirow[t]{3}{*}{ Material type } & \multirow[t]{3}{*}{ Source } & \multicolumn{6}{|c|}{ Mechanical properties in different conditions } & \multirow[t]{3}{*}{ References } \\
\hline & & \multicolumn{2}{|l|}{ Dry } & \multicolumn{2}{|c|}{ Hydrated } & \multicolumn{2}{|c|}{ Submerged at RT } & \\
\hline & & $\sigma_{\text {UTS }}(\mathrm{MPa})$ & $\varepsilon_{\text {UTS }}(\%)$ & $\begin{array}{l}\sigma_{\text {UTS }} \\
(\mathrm{MPa})\end{array}$ & $\varepsilon_{\text {UTS }}(\%)$ & $\sigma_{\text {Uts }}(\mathrm{MPa})$ & $\varepsilon_{\text {UTS }}(\%)$ & \\
\hline Collagen & Bovine tendon & $10.0 \pm 0.5$ & 6 (approx.) & - & - & - & - & Li et al. (2014) \\
\hline Collagen (heat treated at $70^{\circ} \mathrm{C}$ ) & $\begin{array}{l}\text { Ovine type I } \\
\text { solution }\end{array}$ & $\begin{array}{l}90.71 \pm \\
12.91\end{array}$ & $\begin{array}{l}16.79 \pm \\
2.02\end{array}$ & - & - & - & - & $\begin{array}{l}\text { Moreno et al. } \\
\text { (2015) }\end{array}$ \\
\hline Collagen & Rat tail tendons & $\begin{array}{l}80 \\
\text { (approx.) }\end{array}$ & 7 (approx.) & - & - & - & - & $\begin{array}{l}\text { Sionkowska et al. } \\
\text { (2006) }\end{array}$ \\
\hline Collagen & Bovine splits & $49.2 \pm 7.1$ & $13.7 \pm 2.8$ & - & - & - & - & Ding et al. (2015) \\
\hline Collagen (cross-linked) & $\begin{array}{l}\text { Bovine dermal } \\
\text { type I }\end{array}$ & - & - & - & - & Not reported & Not reported & $\begin{array}{l}\text { (Grover et al., } \\
\text { 2012) }\end{array}$ \\
\hline $\begin{array}{l}\text { Collagen (with cross-linking } \\
\text { agents) }\end{array}$ & Cattle skin & $\begin{array}{l}17.25 \pm \\
0.07\end{array}$ & $\begin{array}{l}13.88 \pm \\
0.41\end{array}$ & $\begin{array}{l}2.6 \pm \\
0.05\end{array}$ & $\begin{array}{l}20.94 \pm \\
0.13\end{array}$ & - & - & Wu et al. (2018) \\
\hline Collagen (cross-linked) & Rat tail & - & - & - & - & $\begin{array}{l}\text { Reported load } \\
(0.04 \mathrm{~N} / \mathrm{mm})\end{array}$ & $\begin{array}{l}0.12 \mathrm{~mm} / \mathrm{mm} \\
\text { (approx.) }\end{array}$ & Vrana et al. (2007) \\
\hline Collagen (cross-linked) & Porcine skin & 22 & 18 & - & - & - & - & (Liu et al., 2017) \\
\hline Collagen (non-cross-linked) & $\begin{array}{l}\text { Bovine achilles } \\
\text { tendon }\end{array}$ & - & - & $\begin{array}{l}0.10 \pm \\
0.03\end{array}$ & $\begin{array}{l}40.82 \pm \\
13.52\end{array}$ & - & - & $\begin{array}{l}\text { Delgado et al. } \\
\text { (2017) }\end{array}$ \\
\hline Collagen & & & & & & & & (Liu et al., 2016) \\
\hline Collagen (ageing treatment) & Bovine skin & 36 & 18 & 4 & 18 & - & - & Shi et al. (2019) \\
\hline Collagen (crosslinked) & Tendon & - & - & $\begin{array}{l}7.93 \pm \\
1.03\end{array}$ & $\begin{array}{l}42.17 \pm \\
3.21\end{array}$ & - & - & (Liu et al., 2012) \\
\hline Collagen (cross-linked) & Bovine tendon & - & - & $\begin{array}{l}9.15 \pm \\
0.9\end{array}$ & $48 \pm 2.5$ & - & & Liu et al. (2014) \\
\hline Collagen (cross-linked) & $\begin{array}{l}\text { Bovine skin } \\
\text { splits }\end{array}$ & 17.5 & 2 & 2 & 18 & - & - & Wang et al. (2015) \\
\hline $\begin{array}{l}\text { Collagen- } 1 \% \\
\text { glycosaminoglycans composite }\end{array}$ & Rat tail tendons & 60 & 4 & 1.7 & 15 & - & - & $\begin{array}{l}\text { Kaczmarek et al. } \\
\text { (2018) }\end{array}$ \\
\hline Collagen-cellulose composite & Bovine hide & 25 & 16 & 14 & 25 & - & & Steele et al. (2013) \\
\hline
\end{tabular}


acquired from Sigma-Aldrich. Distilled water was produced in the laboratory.

\subsection{Preparation of collagen films}

Collagen solution $(8 \mathrm{mg} / \mathrm{ml})$ was prepared by adding collagen powder to $0.05 \mathrm{M}$ acetic acid. The solution was stored at $2-6^{\circ} \mathrm{C}$ for $48 \mathrm{~h}$ and then stirred $(1500 \mathrm{rpm})$ for $4 \mathrm{~h}$ at $2-6^{\circ} \mathrm{C}$. The obtained solution was further centrifuged (MSE, Centaur 2) for $180 \mathrm{~s}$ at $2500 \mathrm{rpm}$. Following centrifugation, the solution was stirred at $1500 \mathrm{rpm}$ for $30 \mathrm{~s}$ due to the variation in density throughout the solution. Next, it was degassed for 3 $\mathrm{h}$ to remove micro-bubbles. Finally, the solution was casted in a polystyrene (PS) petri-dish and left to dry in a fume hood at room temperature for a week. The schematic of the whole process for collagen film preparation is depicted in Fig. 1a. The films formed were easy to peel off and semi-transparent (Fig. 1b). There were no visible pores or bubbles on the surface of the films. The films produced were approximately 50 $\mu \mathrm{m}$ thick.

\subsection{FTIR analysis}

The IR spectra of the samples were recorded employing an attenuated total reflectance-Fourier transform infrared (ATR-FTIR) spectrophotometer (IRTracer-100, Shimadzu) at ambient temperature and humidity. The measurements were obtained in the range of 800-4000 $\mathrm{cm}^{-1}$, with a resolution of $4 \mathrm{~cm}^{-1}$. A total of 40 scans were performed for each sample.

The obtained FTIR spectra were used to compare the chemical composition of the films produced and the molecular conformation of processed collagen to the initial collagen powder (Fig. 2). The characteristic absorption peaks for collagen film at 3298, 3076, 1636, 1541 and $1236 \mathrm{~cm}^{-1}$ correspond to amide A, amide B, amide I, amide II and amide III bands, respectively (Sionkowska et al., 2010; Gopinath et al., 2004). These peaks were very close to the ones obtained from the collagen powder, which signifies its characteristic peaks (Sionkowska et al., 2006). The absorption ratios of amide III to $1450 \mathrm{~cm}^{-1}$ peak correspond to the triple-helix configuration of collagen, which should be near 1; values less than 1 indicate a deterioration of triple-helix configuration

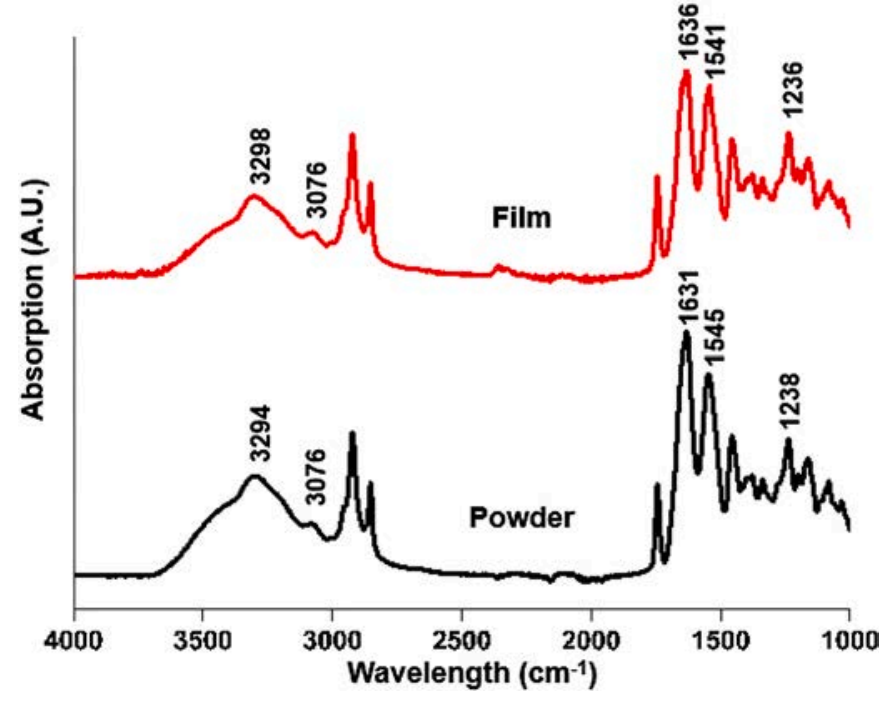

Fig. 2. FTIR spectra for collagen powder and processed film.

(Andrews et al., 2003; Shi et al., 2019). The collagen powder and the film had absorption ratios of 0.98 and 1.01, respectively, indicating the retention of its triple-helix integrity.

\subsection{Mechanical analysis}

Uniaxial tensile tests were performed using the Instron 5944 system with a Bio-Puls temperature-controlled bath (Instron 3130-100 Bio-Puls Bath, Instron, USA) attached to it. A $500 \mathrm{~N}$ load cell was used for all uniaxial tests; it was chosen based on preliminary tests quantifying the range of forces measured and assessing the suitability of the system's precision $(0.5 \mathrm{~N})$. Pneumatic submersible grips modified with rubber straps were employed to avoid sample slippage.

The films were cut into rectangular strips (ASTM D882) of dimensions $45 \mathrm{~mm} \times 5 \mathrm{~mm} \times 0.05 \mathrm{~mm}$ with a gauge length of $20 \mathrm{~mm}$. The following types of conditions were generated to perform uniaxial test at (a)
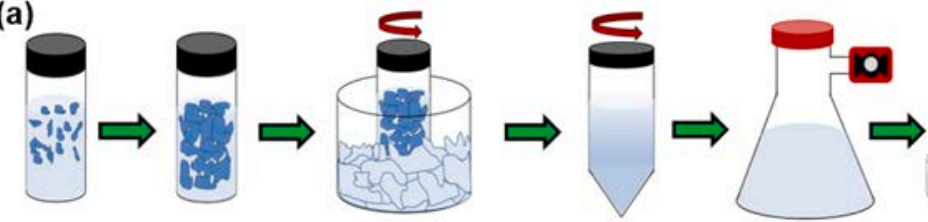

Collagen Fibres fibres in swell after solution $48 \mathrm{hrs}$
Stirring

Centrifugation

Degassing

Solution casting

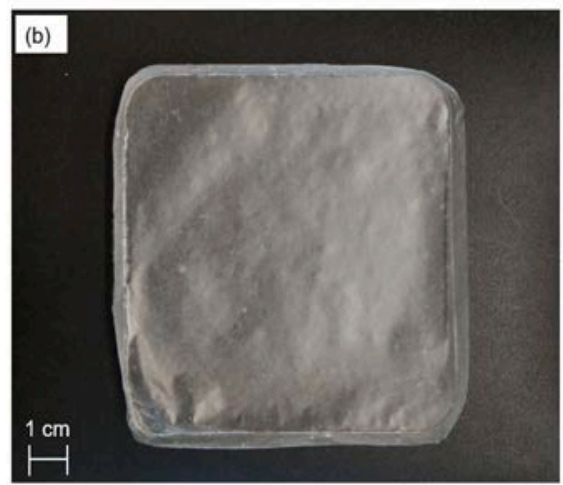

Fig. 1. (a) Schematic of process; (b) collagen films prepared. 
a strain rate of $0.001 \mathrm{~s}^{-1}$ :

(a) dry samples without any further treatment were tested at ambient temperature $\left(20^{\circ} \mathrm{C}\right)$ and humidity to investigate the mechanical response of collagen in ambient conditions;

(b) pre-hydrated (in water for $10 \mathrm{~min}$ ) samples at $20{ }^{\circ} \mathrm{C}$ were tested in air to assess the effect of hydration on collagen. In the lab, the humidifier maintained constant humidity, and no visual signs of drying out of the hydrated samples were observed until failure;

(c) pre-hydrated (in water for $10 \mathrm{~min}$ ) samples were tested at ambient (water) temperature $\left(20^{\circ} \mathrm{C}\right)$ and in submerged conditions to analyse the effect of submersion on collagen film;

(d) pre-hydrated (in water at $37^{\circ} \mathrm{C}$ for $10 \mathrm{~min}$ ) samples were tested at physiological temperature $\left(37^{\circ} \mathrm{C}\right)$ and in submerged conditions to explore the change in the mechanical response of the collagen film upon submersion in-aqua at elevated temperature. This condition emulated the in-vivo conditions for potential biomedical applications of collagen films. The abbreviations and different conditions of testing of the samples are provided in Table 2 ( $\mathrm{n}$ represents the number of samples tested).

The thickness of the films was measured for at least 5 readings across different regions of each sample prior to the test. The thickness of the $\mathrm{Col}_{\mathrm{D}}$ was obtained by measuring the dry films $(50 \mu \mathrm{m} \pm 10 \mu \mathrm{m})$ while for $\mathrm{Col}_{\mathrm{H}}, \mathrm{Col}_{\mathrm{A}}$ and $\mathrm{Col}_{\mathrm{AT}}$ samples thickness were measured after prehydrating in water $(70 \mu \mathrm{m} \pm 10 \mu \mathrm{m})$ for $10 \mathrm{~min}$. All the stress-strain graphs reported in this work are the true stress-strain curves.

To investigate the strain-rate-dependent behaviour of the collagen film, tensile samples $(n=7)$ were subjected to uniaxial tension under a broad range of strain rates: $0.0001 \mathrm{~s}^{-1}, 0.001 \mathrm{~s}^{-1}, 0.01 \mathrm{~s}^{-1}, 0.1 \mathrm{~s}^{-1}$ and 1 $\mathrm{s}^{-1}$. All these experiments were carried out at ambient temperature and humidity.

All the experimental data were statistically analysed using at least seven replicates (for each group) and reported as mean \pm standard deviation (SD).

\section{Results and discussions}

\subsection{In-plane isotropic behaviour}

Collagenous tissues such as tendons (Lynch et al., 2003), cartilages (Jurvelin et al., 2003) and skin (Ottenio et al., 2015; Pissarenko et al., 2019) show anisotropic behaviour due to the difference in the alignment of collagen fibrils.

The absence of any specific in-plane orientation in the film preparation (Fi g. 3) together with the measurements along two main directions suggests that such collagen films could be transversally isotropic. The mechanical properties for $\mathrm{x}$ - and $\mathrm{y}$-directions are close: the ultimate tensile stress (UTS) for the specimens: $71.21 \pm 11.3 \mathrm{MPa}$ and $75.7 \pm 15.7 \mathrm{MPa}$, while the strain at failure: $23.22 \pm 3.36 \%$ and $23.5 \pm 2.5 \%$, ( $\mathrm{n}=7$, tested for each direction), respectively. This transversely isotropic behaviour (out-of-plane compression tests demonstrated the behaviour different from the in-plane one) may be attributed to the fact that collagen solution was poured into squareshaped petri-dishes (Fig. 3), with no control on the orientation during

Table 2

Different environmental conditions used for uniaxial tensile test.

\begin{tabular}{llll}
\hline $\begin{array}{l}\text { Specimen } \\
\text { name }\end{array}$ & $\begin{array}{l}\text { Testing } \\
\text { environment }\end{array}$ & $\begin{array}{l}\text { Testing } \\
\text { temperature }\end{array}$ & $\begin{array}{l}\text { Specimen } \\
\text { conditioning }\end{array}$ \\
\hline $\mathrm{Col}_{\mathrm{D}}(\mathrm{n}=7)$ & Ambient & $\mathrm{RT}\left(20^{\circ} \mathrm{C}\right)$ & Dry \\
$\mathrm{Col}_{\mathrm{H}}(\mathrm{n}=7)$ & Ambient & $\mathrm{RT}\left(20^{\circ} \mathrm{C}\right)$ & Pre-hydrated \\
$\mathrm{Col}_{\mathrm{A}}(\mathrm{n}=7)$ & In-aqua & $\mathrm{RT}\left(20^{\circ} \mathrm{C}\right)$ & Pre-hydrated \\
$\mathrm{Col}_{\mathrm{AT}}(\mathrm{n}=7)$ & In-aqua & $\mathrm{PT}\left(37^{\circ} \mathrm{C}\right)$ & $\begin{array}{l}\text { Pre-hydrated at } 37 \\
\end{array}$ \\
& & & ${ }^{\circ} \mathrm{C}$ \\
\hline
\end{tabular}

solution dispersion, in contrast to natural collagens, with their orientation defined by the growth of biotissues. Moreover, the film samples were not drawn in any specific direction that could lead to deformationinduced anisotropy. So, in the subsequent studies, the films were not considered for anisotropy.

\subsection{Effect of environmental conditions}

Tensile measurements of the collagen film were carried out in four different testing conditions mentioned in Table 2. The stress-strain scatter band curves for each of the environmental conditions are plotted in Fig. 4a. Mean values of ultimate tensile strength (UTS), strain at failure, resilience and toughness were extracted from the stress-strain responses and are presented in Table 3 . $\mathrm{Col}_{\mathrm{D}}$ exhibited the highest levels of tensile strength $(75.7 \pm 15.7 \mathrm{MPa})$, resilience $\left(934.4 \pm 282.6 \mathrm{MJ} / \mathrm{m}^{3}\right)$ and toughness $\left(1022 \pm 309.2 \mathrm{MJ} / \mathrm{m}^{3}\right)$ but the lowest level of strain at failure $(23.5 \pm 2.5 \%)$. A considerable change in the stress-strain curves was observed when the film samples were either hydrated $\left(\mathrm{Col}_{\mathrm{H}}\right)$ or tested in submerged $\left(\mathrm{Col}_{\mathrm{A}}\right.$ and $\left.\mathrm{Col}_{\mathrm{AT}}\right)$ conditions.

The stress-strain behaviour of $\mathrm{Col}_{\mathrm{D}}$ films demonstrated an elasticplastic-strain hardening behaviour (Fig. 4a), reported earlier by Sionkowska et al. (2006); Moreno et al. (2015); Steele et al. (2013). However, in presence of water, $\left(\mathrm{Col}_{\mathrm{H}}, \mathrm{Col}_{\mathrm{A}}\right.$ and $\left.\mathrm{Col}_{\mathrm{AT}}\right)$ films revealed the hyperelastic nature (Fig. 4a, inset) of collagen, typically observed in biological tissues such as skin (Pissarenko et al., 2019), which may be also referred to as $J$ stress-strain curve (Falini et al., 2004; Steele et al., 2013). The increase in the strain at failure in $\mathrm{Col}_{\mathrm{H}}, \mathrm{Col}_{\mathrm{A}}$ and $\mathrm{Col}_{\mathrm{AT}}$ may be attributed to the sliding of the collagen fibrils thanks to the presence of water molecules (Yang et al., 2015; Gautieri et al., 2012); this resulted in a vivid necking followed by a ductile failure (Fig. 4b). The lack of water molecules caused $\mathrm{Col}_{D}$ to exhibit the strain-hardening response, which eventually led to a brittle failure with a drastic increase in resilience and toughness (see Table 3 ).

Collagen films $\left(\mathrm{Col}_{\mathrm{A}}\right.$ and $\left.\mathrm{Col}_{\mathrm{AT}}\right)$ tested in submerged conditions exhibited a drop in tensile strength by $10.2 \%$ of $\mathrm{Col}_{\mathrm{H}}$, while the strain at
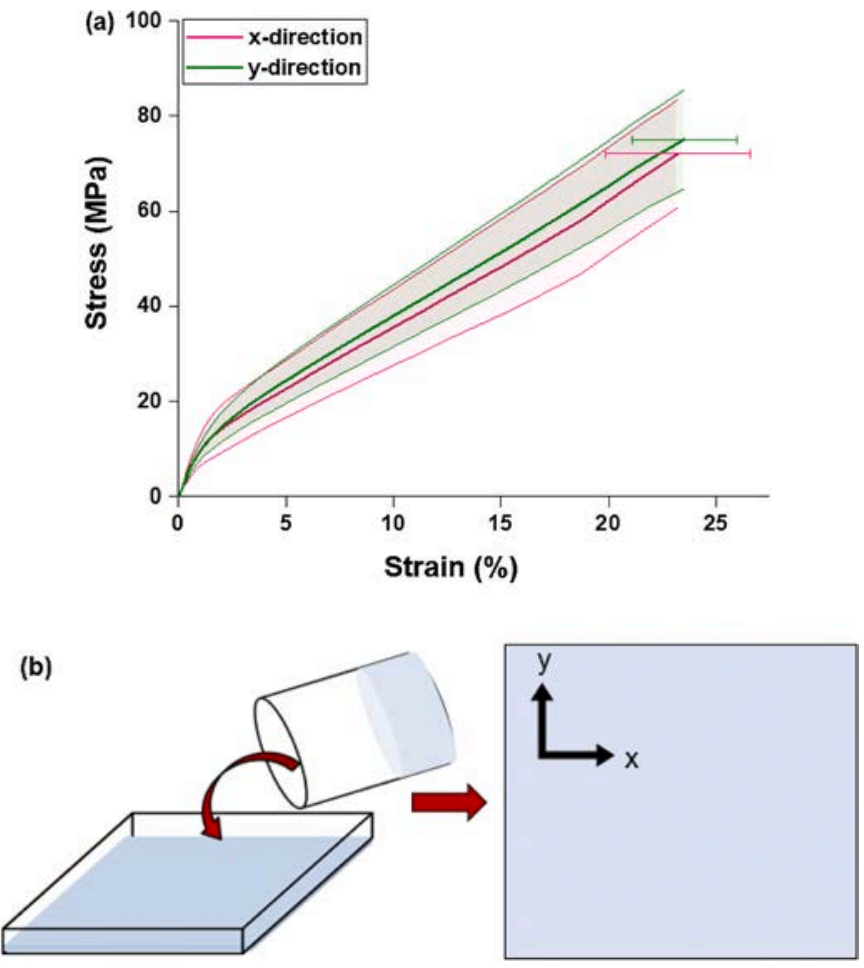

Fig. 3. (a) Stress-strain curves of collagen film for $x$ - and y-directions; (b) collagen solution poured in petri-dish with no control in fibril orientation. 

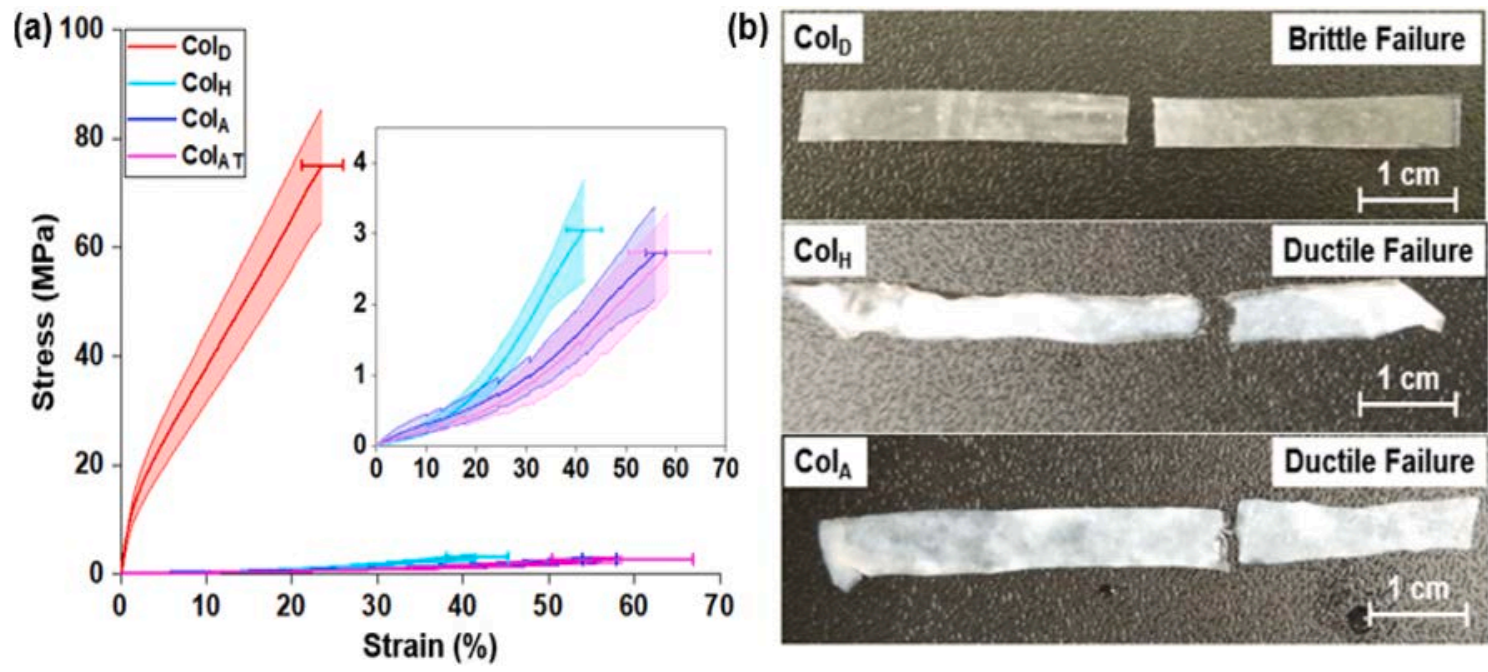

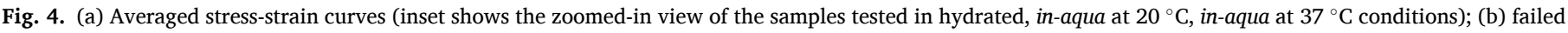
specimens of collagen film tested in different environmental conditions.

Table 3

Mechanical properties in different environmental conditions.

\begin{tabular}{lllll}
\hline & $\begin{array}{l}\text { Ultimate Tensile } \\
\text { Strength (MPa) }\end{array}$ & $\begin{array}{l}\text { Ultimate Tensile } \\
\text { Strain (\%) }\end{array}$ & $\begin{array}{l}\text { Resilience } \\
\left(\mathrm{MJ} / \mathrm{m}^{3}\right)\end{array}$ & $\begin{array}{l}\text { Toughness } \\
\left(\mathrm{MJ} / \mathrm{m}^{3}\right)\end{array}$ \\
\hline $\mathrm{Col}_{\mathrm{D}}$ & $75.7 \pm 15.7$ & $23.5 \pm 2.5$ & $934.4 \pm 282.6$ & $1022 \pm 309.2$ \\
$\mathrm{Col}_{\mathrm{H}}$ & $3.05 \pm 1.31$ & $41.3 \pm 3.6$ & $57.3 \pm 20.9$ & $57.1 \pm 21.3$ \\
$\mathrm{Col}_{\mathrm{A}}$ & $2.74 \pm 1.00$ & $55.9 \pm 2.0$ & $60.2 \pm 14.4$ & $67.5 \pm 16.4$ \\
$\mathrm{Col}_{\mathrm{AT}}$ & $2.71 \pm 1.10$ & $58.0 \pm 8.3$ & $58.9 \pm 10.0$ & $66.1 \pm 12.4$ \\
\hline
\end{tabular}

failure for $\mathrm{Col}_{\mathrm{A}}$ and $\mathrm{Col}_{\mathrm{AT}}$ increased to about $35.3 \%$ and $40.4 \%$, respectively. This increase in ductility may be attributed to the continuous presence of water molecules, which not only provides enough space for the fibrils to move around and elongate (Yang et al., 2015; Gautieri et al., 2012) but also results in more plasticizing effect (Yuan and Verma, 2006). The increase in temperature (of Bio-Bath) from $20^{\circ} \mathrm{C}$ (RT) to $37{ }^{\circ} \mathrm{C}$ (PT) for $\mathrm{Col}_{\mathrm{A}}$ and $\mathrm{Col}_{\mathrm{AT}}$, respectively, did not show any significant difference in mechanical properties (Table 3 ) of collagen films.

The tangent modulus for $\mathrm{Col}_{\mathrm{D}}$ is plotted in Fig. 5 against the applied strain to understand the instantenous mechanical response of dry collagen with increase in the strain level. It was obtained from the stressstrain graphs by differentiation with regard to strain.

The evolution of modulus for $\mathrm{Col}_{\mathrm{D}}$ exhibits a non-linear behaviour, more precisely - a three-phasic behaviour. The modulus-strain curve (Fig. 5) depicts three main characteristic stages, with a failure region at the end: (a) Stage I - up to $\varepsilon_{1}$ (initial non-linear region): the modulus (initial or maximum modulus, $E_{\max }$ ) decreases abruptly, which is related to the sudden rupture in collagen fibrillar bundles; (b) Stage II - $\varepsilon_{1}-\varepsilon_{2}$ (quasi-linear region): the modulus remains nearly constant (linear modulus, $\left.E_{\mathrm{II}}\right)$ throughout this region, indicating a gradual stress transfer between the fibrils (c) Stage III $-\varepsilon_{2}-\varepsilon_{\text {UTS }}$ (failure region): there is a sudden drop in the modulus, reflecting the ultimate breakage of the fibrils. A similar non-linear response was observed in flax-reinforced composites with structural hierarchy (Gager et al., 2019; Jeannin et al., 2019). $\varepsilon_{1}, \varepsilon_{2}$ and $\varepsilon_{\text {UTS }}$ denote the strain levels corresponding to at the end of Stage I, II and III (ultimate tensile strain), respectively.

Collagen behaved very differently in presence of water, exhibiting a completely different mechanical response, (as compared to $\mathrm{Col}_{\mathrm{D}}$ ). The average normalised modulus-strain curves of $\mathrm{Col}_{\mathrm{H}}, \mathrm{Col}_{\mathrm{A}}$, and $\mathrm{Col}_{\mathrm{AT}}$ with the corresponding error bars are presented in Fig. 6. The modulus-strain

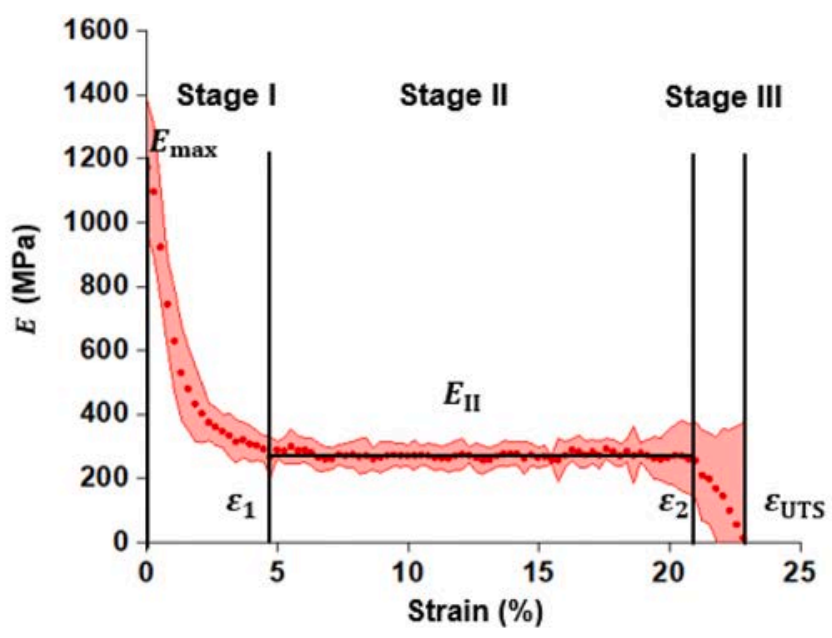

\begin{tabular}{|c|c|c|c|c|}
\hline$E_{\max }(\mathrm{MPa})$ & $E_{\mathrm{II}}(\mathrm{MPa})$ & $\varepsilon_{1}(\%)$ & $\varepsilon_{2}(\%)$ & $\varepsilon_{\mathrm{UTS}}(\%)$ \\
\hline $1172 \pm 193.3$ & $273.5 \pm 33.1$ & $4.83 \pm 0.5$ & $20.73 \pm 2.6$ & $23.5 \pm 2.5$ \\
\hline
\end{tabular}

Fig. 5. Evolution of averaged tangent modulus of $\mathrm{Col}_{\mathrm{D}}$ subjected to uniaxial tension (with corresponding mechanical parameters for each characteristic stage). 
behaviour may be categorised into four characteristic stages as introduced in Fig. 6 (inset): (a) Stage I - up to $\varepsilon_{1}$ (initial quasi-linear response): the modulus in this regime is nearly constant (or declining) (initial modulus, $E_{\mathrm{I}}$ ), which indicates that the underlying collagen fibrils are not fully engaged in the load-transfer mechanism; (b) Stage II $\varepsilon_{1}-\varepsilon_{2}$ (a non-linear response): the modulus increases gradually with the increase in strain, reflecting the gradual recruitment of collagen fibrils. This stage may be referred to as materialstiffening stage; (c)Stage III - $\varepsilon_{2}-\varepsilon_{3}$ (a quasi-linear response); the modulus is almost constant (linear modulus, $E_{\text {III }}$ ), indicating realignment of the fibrils along the loading direction; (d) Stage IV - $\varepsilon_{3}-\varepsilon_{\text {UTS (a failure region): the modulus }}$ decreases rapidly in this regime, indicating the failure of the fibrils. The collagen films subjected to hydration or in-aqua conditions (submersion) exhibited a similar response to that observed for bacterial cellulose hydrogel (Gao et al., 2016). $\varepsilon_{1}, \varepsilon_{2}, \varepsilon_{3}$ and $\varepsilon_{\text {UTS }}$ denote the strain magnitude at the end of Stage I, II, III and IV (ultimate tensile strain), respectively.

The magnitudes of $E_{\mathrm{I}}$ and $E_{\mathrm{III}}$ decreased and the strain range increased in each characteristic stage when samples were submerged $\left(\mathrm{Col}_{\mathrm{A}}\right.$, and $\left.\mathrm{Col}_{\mathrm{AT}}\right)$ as compared to hydrated $\left(\mathrm{Col}_{\mathrm{H}}\right)$. It is worth mentioning that the effect of temperature $\left(\mathrm{Col}_{\mathrm{AT}}\right)$ was observed in the modulus-strain curve (Fig. 6), with some increase found in respective characteristic stages as compared to $\mathrm{Col}_{\mathrm{A}}$. The increase in Stage II was more profound, indicating that at elevated temperature $\left(37{ }^{\circ} \mathrm{C}\right)$ the collagen fibrils relax; thus, the gradual recruitment of fibrils takes a longer period.

\subsection{Parameters of hyperelastic model}

To characterise the non-linear material behaviour of the collagen specimens in different environmental conditions and to quantify the constitutive models for further studies, the averaged experimental test data obtained from uniaxial tensile tests were fitted to the established hyperelastic material models using Abaqus software.

In case of $\mathrm{Col}_{\mathrm{D}}$, the Mooney-Rivlin (Mooney, 1940), second-order polynomial and Ogden (1972) models fitted best with the experimental results (Fig. 7a), while for $\mathrm{Col}_{\mathrm{H}}, \mathrm{Col}_{\mathrm{A}}$ and $\mathrm{Col}_{\mathrm{AT}}$ the most suitable schemes were the second-order polynomial, Yeoh (1993) and Ogden (1972) (Fig. 7b-d). The model parameters obtained from these curve fitting are presented in Table 4.

The material constants obtained for the hyperleastic models are suitable for future simulations. In case of $\mathrm{Col}_{\mathrm{D}}$, all the three models (MRmodel, second order polynomial, Ogden model) exhibited a very good correlation (consider the values of the coefficient of determination $\left(R^{2}\right)$ in Table 4). Thus, while simulating collagen at ambient conditions any of these models should provide realistic results. However, mechanical behaviour of $\mathrm{Col}_{\mathrm{H}}, \mathrm{Col}_{\mathrm{A}}$ and $\mathrm{Col}_{\mathrm{AT}}$ specimens was affected by water; thus, the material constants obtained from these tests are very different from those for $\mathrm{Col}_{\mathrm{D}}$. Though all the models considered for $\mathrm{Col}_{\mathrm{H}}, \mathrm{Col}_{\mathrm{A}}$ and $\mathrm{Col}_{\mathrm{AT}}$ demonstrated a high degree of correlation with the experimental data, the material constants obtained with the second-order polynomial model presented a significant difference in values. In case of the Yeoh model, its material parameters obtained for $\mathrm{Col}_{\mathrm{A}}$, and $\mathrm{Col}_{\mathrm{AT}}$ were in good agreement while those for $\mathrm{Col}_{\mathrm{H}}$ showed reasonable values. The material parameters obtained with the Ogden model demonstrated the best agreement between $\mathrm{Col}_{\mathrm{A}}$, and $\mathrm{Col}_{\mathrm{AT}}$, with those for $\mathrm{Col}_{\mathrm{H}}$ in close proximity. Thus, it may be concluded that while modelling wet or in-vivo collagen specimens, the parameters obtained with the Ogden model should closely reproduced the deformational behaviour of collagen.

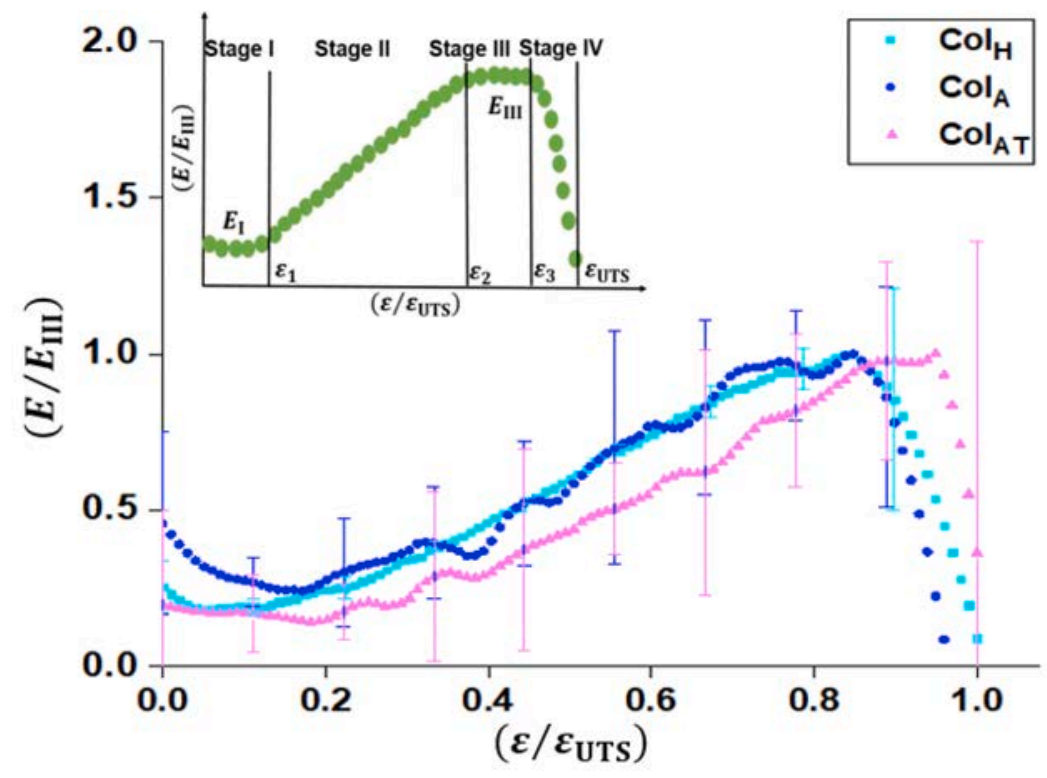

\begin{tabular}{|c|c|c|c|c|c|c|}
\hline & $\boldsymbol{E}_{\mathbf{I}}(\mathrm{MPa})$ & $\boldsymbol{E}_{\mathrm{III}}(\mathrm{MPa})$ & $\boldsymbol{\varepsilon}_{\mathbf{1}} \mathbf{( \% )}$ & $\boldsymbol{\varepsilon}_{\mathbf{2}}(\mathbf{\%})$ & $\boldsymbol{\varepsilon}_{\mathbf{3}} \mathbf{( \% )}$ & $\boldsymbol{\varepsilon}_{\mathrm{UTS}} \mathbf{( \% )}$ \\
\hline $\mathrm{Col}_{\mathrm{H}}$ & $2.88 \pm 0.74$ & $13.7 \pm 1.72$ & $7.12 \pm 0.84$ & $32.5 \pm 1.5$ & $37.5 \pm 2.4$ & $41.3 \pm 3.6$ \\
\hline $\mathrm{Col}_{\boldsymbol{\Lambda}}$ & $2.72 \pm 1.04$ & $8.73 \pm 0.97$ & $10.6 \pm 0.72$ & $41.2 \pm 1.3$ & $51.9 \pm 1.7$ & $55.9 \pm 2.0$ \\
\hline $\mathrm{Col}_{\boldsymbol{A T}}$ & $1.72 \pm 0.22$ & $9.24 \pm 0.52$ & $10.9 \pm 0.59$ & $50.8 \pm 0.9$ & $55.9 \pm 0.7$ & $58.0 \pm 8.6$ \\
\hline
\end{tabular}

Fig. 6. Evolution of averaged normalised tangent modulus ( $E_{\mathrm{III}}$ ) with normalised strain (at UTS) for $\mathrm{Col}_{\mathrm{H}}, \mathrm{Col}_{\mathrm{A}}$, and $\mathrm{Col}_{\mathrm{AT}}$ (inset shows the schematic for modulus evolution in each characteristic stage). 

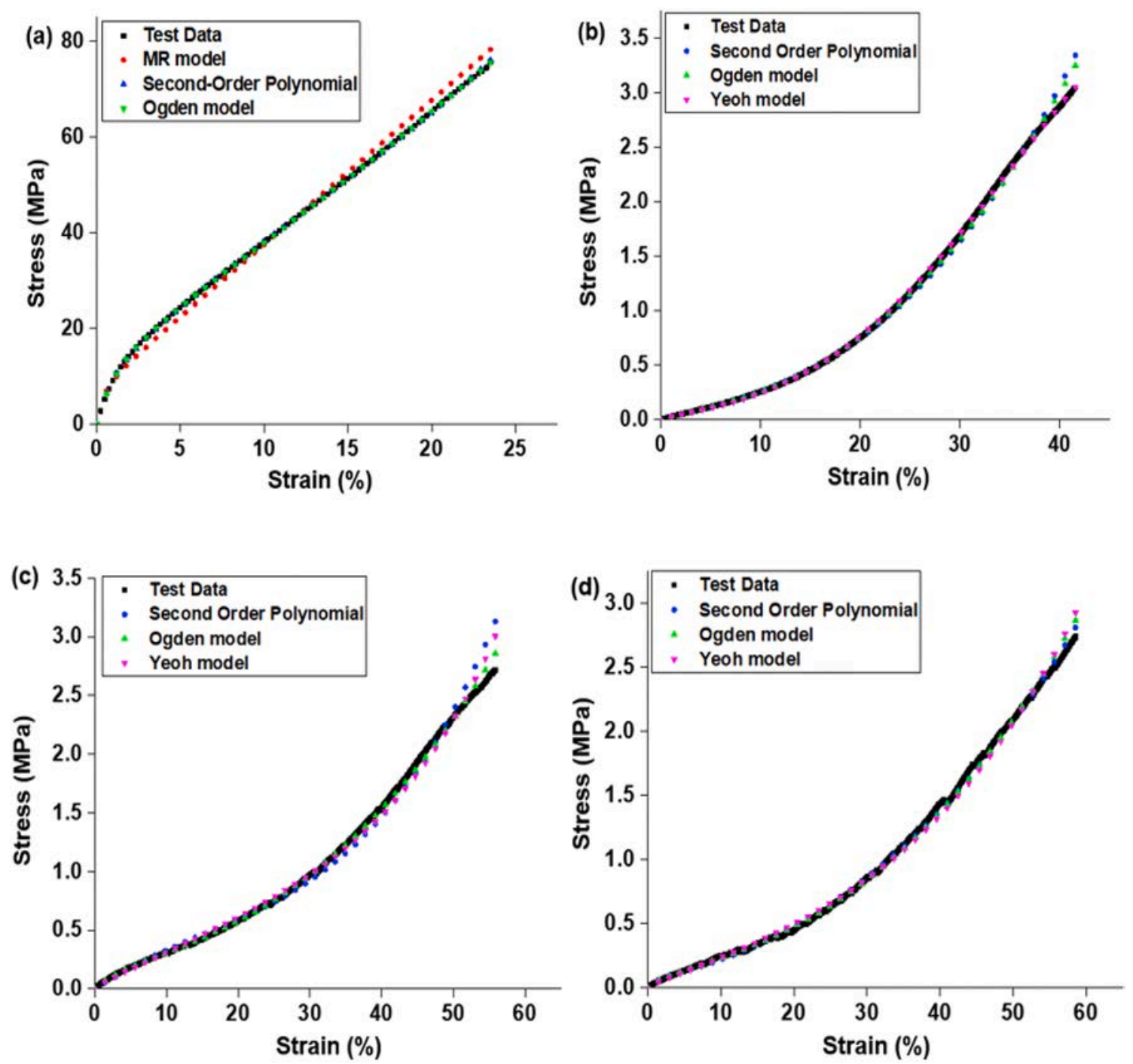

Fig. 7. Stress-strain response of averaged $\mathrm{Col}_{\mathrm{D}}(\mathrm{a}), \mathrm{Col}_{\mathrm{H}}(\mathrm{b}), \mathrm{Col}_{\mathrm{A}}(\mathrm{c})$ and $\mathrm{Col}_{\mathrm{AT}}(\mathrm{d})$ fitted in Abaqus using different hyperelastic constitutive equations

\subsection{Effect of strain rate}

\subsubsection{Mechanical response under various strain rates}

The tensile measurements of the dry collagen films were carried out at different strain rates, varying from quasi-static $\left(0.0001 \mathrm{~s}^{-1}\right)$ to intermediate $\left(0.001 \mathrm{~s}^{-1}, 0.01 \mathrm{~s}^{-1}\right)$ to dynamic $\left(0.1 \mathrm{~s}^{-1}, 1 \mathrm{~s}^{-1}\right)$ conditions. The stress-strain response obtained from the wide strain-rate range is plotted as scatter bands in Fig. 8.

The stress-strain curves obtained for collagen films subjected to various strain rates demonstrated an increase in the initial linear stage, with the increase in the strain rate $\left(0.0001 \mathrm{~s}^{-1}\right.$ to $\left.0.1 \mathrm{~s}^{-1}\right)$. This was followed by a non-linear transition to a stage with a nearly constant strain-hardening, which may be related to the initiation of inelastic deformation and damage. The films failed without any visual signs of necking, i.e. in a brittle manner. The stress-strain response of the collagen film tested at dynamic loading $\left(1 \mathrm{~s}^{-1}\right)$ (shown as inset in Fig. 8) exhibits an initial slack related to transient loading conditions, followed by an elastic regime and a strain-hardening stage. The elastic regime was rather long compared to that for other strain rates, while the hardening regime exhibited a more gradual transition. The hardening region is a short-lived process, which may be attributed to dynamic loading, where the underlying fibrillar deformation leads to rapid failure at a matrixfibril interface (Karunaratne et al., 2018). A significant difference in the strain at failure was also observed compared to from other stress-strain curves.

The evolution of the tangent modulus with strain for various strain rates is plotted in Fig. 9. As mentioned above, the tangent modulus was used to characterise the stiffness of a material. All the curves in Fig. 9 exhibited two characteristics stages, followed by a failure region: Stage I - up to $\varepsilon_{1}$ (initial non-linear stage): a sudden drop in the modulus, which might be attributed to a sudden rupture of the bundles of collagen fibrils; Stage II $-\varepsilon_{1}-\varepsilon_{2}$ (a quasi-linear region): a regime, with an almost constant modulus, demonstrating a stress-transfer between the fibrils. The cross in the graphs denote the failure of the collagen films, which may be considered as Stage III, where there is a sudden drop in the modulus. This region is not shown in Fig. 9 to avoid making it busy. The inset in Fig. 9 is used to present the data for the tangent modulus of the collagen film subjected to the strain rates of $1 \mathrm{~s}^{-1}$. In this case, the discussed two characteristic stages were preceded by a transitional regime up to $\varepsilon_{0}$, related to the transient loading. Thus, this should not be considered as a characteristic stage. A similar response was observed in flax-reinforced composites due to the complex fibrillar structure of flax (Gager et al., 2019; Jeannin et al., 2019). $\varepsilon_{1}$ and $\varepsilon_{2}$ are the strain levels percent at the end of Stages I and II, respectively, while $\varepsilon_{0}$ denotes the strain generated at the end of the transitional regime.

The strain-rate-dependent behaviour of collagen may be quantified with various mechanical parameters for the characteristic stages. The dependence of maximum $\left(E_{\max }\right)$ and linear $\left(E_{\mathrm{II}}\right)$ moduli on the strain rate 
Table 4

Parameters obtained from fitting of experimental mechanical data for collagen film tested under different environmental conditions.

\begin{tabular}{|c|c|c|c|c|c|c|}
\hline \multirow[t]{2}{*}{ Model } & \multirow[t]{2}{*}{ Equations } & \multicolumn{5}{|c|}{ Sample Type } \\
\hline & & $\begin{array}{l}\text { Parameters } \\
(\mathrm{MPa})\end{array}$ & $\mathrm{Col}_{\mathrm{D}}$ & $\mathrm{Col}_{\mathrm{H}}$ & $\mathrm{Col}_{\mathrm{A}}$ & $\mathrm{Col}_{\mathrm{AT}}$ \\
\hline \multirow[t]{3}{*}{ Mooney-Rivlin } & \multirow[t]{3}{*}{$C_{10}\left(\bar{I}_{1}-3\right)+C_{01}\left(\bar{I}_{2}-3\right)$} & $C_{10}$ & 1.503 & - & - & - \\
\hline & & $C_{01}$ & 2.259 & - & - & - \\
\hline & & $R^{2}$ & 0.9984 & - & - & - \\
\hline \multirow[t]{6}{*}{$\begin{array}{r}\text { Second-Order } \\
\text { Polynomial }\end{array}$} & \multirow[t]{6}{*}{$\begin{array}{l}C_{10}\left(\bar{I}_{1}-3\right)+C_{01}\left(\bar{I}_{2}-3\right)+C_{11}\left(\bar{I}_{1}-3\right)\left(\bar{I}_{2}-3\right)+C_{20}\left(\bar{I}_{1}-3\right)^{2}+ \\
C_{02}\left(\bar{I}_{2}-3\right)^{2}\end{array}$} & $C_{10}$ & 8.366 & 0.016 & $\begin{array}{l}-7.37 \mathrm{E}- \\
02\end{array}$ & 7.75E-02 \\
\hline & & $C_{01}$ & -7.062 & -0.012 & 0.113 & $\begin{array}{l}-8.21 \mathrm{E}- \\
02\end{array}$ \\
\hline & & $C_{11}$ & $\begin{array}{l}4.00 \mathrm{E}- \\
4\end{array}$ & $6.32 \mathrm{E}-06$ & $\begin{array}{l}-2.03 \mathrm{E}- \\
04\end{array}$ & $6.29 \mathrm{E}-05$ \\
\hline & & $C_{20}$ & -0.011 & 6.07E-05 & $6.14 \mathrm{E}-06$ & $9.05 \mathrm{E}-07$ \\
\hline & & $C_{02}$ & -1.66 & $\begin{array}{l}-1.87 \mathrm{E}- \\
03\end{array}$ & $2.40 \mathrm{E}-02$ & $\begin{array}{l}-1.79 E- \\
02\end{array}$ \\
\hline & & $R^{2}$ & 0.9998 & 0.9944 & 0.9824 & 0.9982 \\
\hline \multirow[t]{4}{*}{ Yeoh Model } & \multirow[t]{4}{*}{$C_{10}\left(\bar{I}_{1}-3\right)+C_{20}\left(\bar{I}_{1}-3\right)^{2}+C_{30}\left(\bar{I}_{1}-3\right)^{3}$} & $C_{10}$ & - & 8.23E-03 & $1.40 \mathrm{E}-02$ & $1.03 \mathrm{E}-02$ \\
\hline & & $C_{20}$ & - & $1.27 \mathrm{E}-05$ & 4.13E-07 & $1.61 \mathrm{E}-06$ \\
\hline & & $C_{30}$ & - & $\begin{array}{l}-1.89 \mathrm{E}- \\
09\end{array}$ & $3.08 \mathrm{E}-10$ & 7.30E-11 \\
\hline & & $R^{2}$ & - & 0.9996 & 0.9876 & 0.9944 \\
\hline \multirow[t]{7}{*}{ Ogden Model $(N=3)$} & \multirow{7}{*}{$U=\sum_{i=1}^{N} \frac{2 \mu_{\mathrm{i}}}{\alpha_{\mathrm{i}}^{2}}\left(\bar{\lambda}_{1}^{\alpha_{\mathrm{i}}}+\bar{\lambda}_{2}^{\alpha_{\mathrm{i}}}+\bar{\lambda}_{3}^{\alpha_{\mathrm{i}}}-3\right)$} & $\mu_{1}$ & 9.975 & 0.345 & 0.276 & 0.205 \\
\hline & & $\mu_{2}$ & 0.217 & $1.03 \mathrm{E}-03$ & $1.59 \mathrm{E}-04$ & 2.03E-04 \\
\hline & & $\mu_{3}$ & -6.541 & -0.338 & -0.248 & -0.182 \\
\hline & & $\alpha_{1}$ & 1.486 & 0.857 & 1.286 & 1.340 \\
\hline & & $\alpha_{2}$ & 2.637 & 3.264 & 3.496 & 3.420 \\
\hline & & $\alpha_{3}$ & -2.90 & 0.703 & 1.114 & 1.214 \\
\hline & & $R^{2}$ & 0.9998 & 0.9970 & 0.9958 & 0.9974 \\
\hline
\end{tabular}

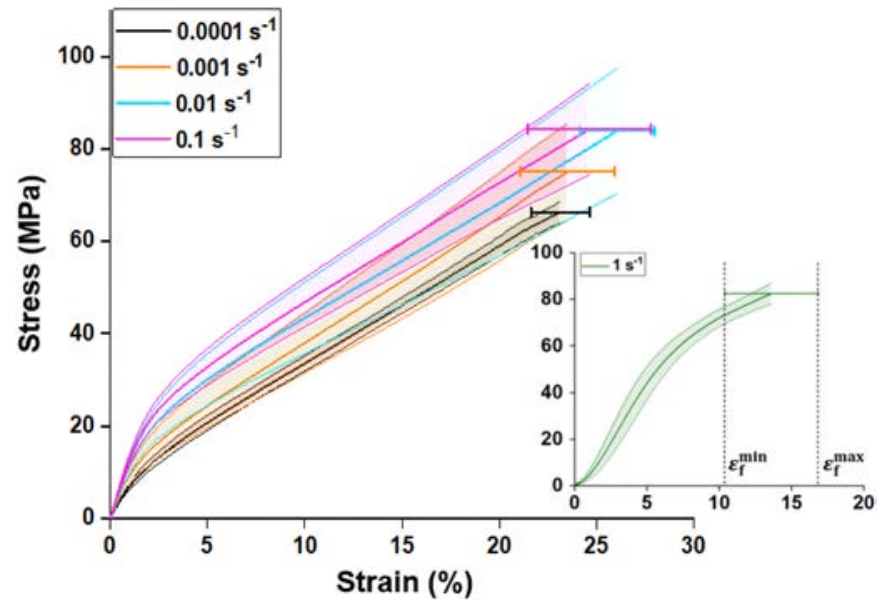

Fig. 8. Scatter bands of stress-strain curves of collagen film under various strain rates (inset shows the scatter band of stress-strain graph for $1 \mathrm{~s}^{-1}$ ).

is shown in Fig. 10a. $E_{\max }$ (at the beginning of Stage I) increased gradually with the increase in the strain rate up to $0.1 \mathrm{~s}^{-1}$ from $858.4 \pm 87.4$ MPa (at $0.0001 \mathrm{~s}^{-1}$ ) to $1444.5 \pm 141.3 \mathrm{MPa}\left(0.1 \mathrm{~s}^{-1}\right)$, indicating a strain-rate-dependent hardening behaviour. The linear modulus $\left(E_{\mathrm{II}}\right)$ obtained for the characteristic Stage II had nearly the same magnitude for strain rates up to $0.1 \mathrm{~s}^{-1}$. However, for the dynamic regime (strain rate of $1 \mathrm{~s}^{-1}$ ) for $E_{\max }$ and $E_{\mathrm{II}}$, a decrease and increase in the modulus was observed, respectively, which might be due to transient loading that did not provide enough exposure to underlying collagen fibrils. The extent of characteristic stages, denoted by strain values $\varepsilon_{1}$ and $\varepsilon_{2}$ defined as a fraction of the ultimate strain $\varepsilon_{\mathrm{UTS}}\left(\frac{\varepsilon_{\mathrm{i}}}{\varepsilon_{\mathrm{UTS}}}, i=1,2\right)$ is presented in Fig. 10b. It was found that Stage II was the most prominent one, with Stage I occupying a minor portion and Stage III depicting a brittle

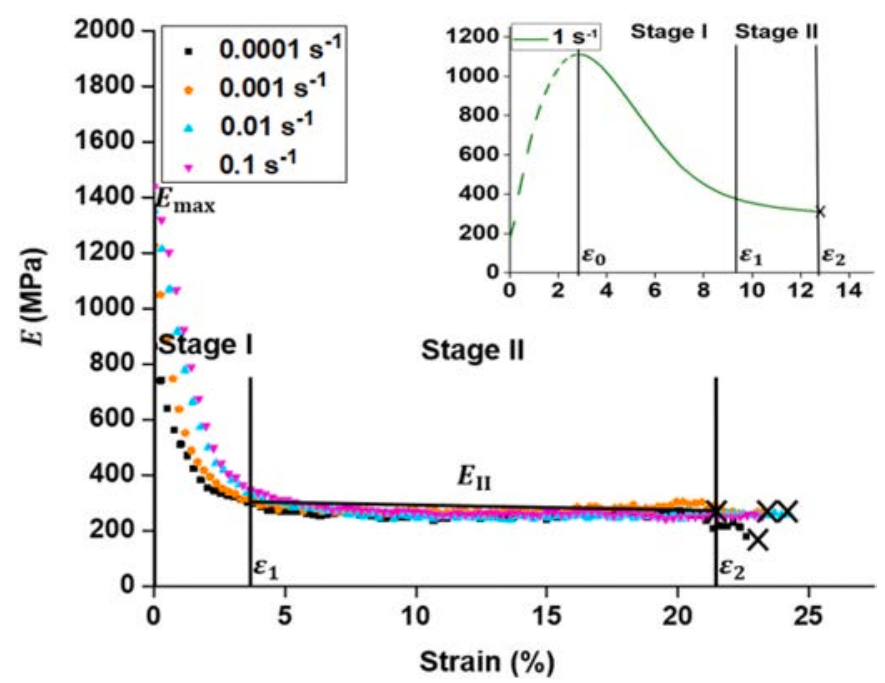

Fig. 9. Evolution of tangent modulus of collagen films subjected to various strain rates at ambient conditions (inset shows the graph for dynamic strain rate $\left.1 \mathrm{~s}^{-1}\right)$.

failure. Stage I was more prominent at quasi-static strain rate of 0.0001 $\mathrm{s}^{-1}$ as the collagen bundles were loaded slowly. For tests at $1 \mathrm{~s}^{-1}$, the box in Fig. 10b shows the characteristic stages, with a black square representing the end of transient loading of the specimen. Stage I was more prominent in this case (compared to other strain rates), indicating the insufficient time for stress transfer within the fibrils.

The gradual increase in the ultimate tensile stress $\left(\sigma_{\text {UTS }}\right)$ (Fig. 10c) from $66.5 \pm 4.5 \mathrm{MPa}$ (at $0.0001 \mathrm{~s}^{-1}$ ) to $84.9 \pm 10.5 \mathrm{MPa}\left(\right.$ at $0.1 \mathrm{~s}^{-1}$ ), indicates a strain-rate-induced hardening behaviour of collagen (earlier reported in collagen-based tissues (Clemmer et al., 2010; Bonner et al., 2015; Pissarenko et al., 2019; Ottenio et al., 2015)). The strain at failure 

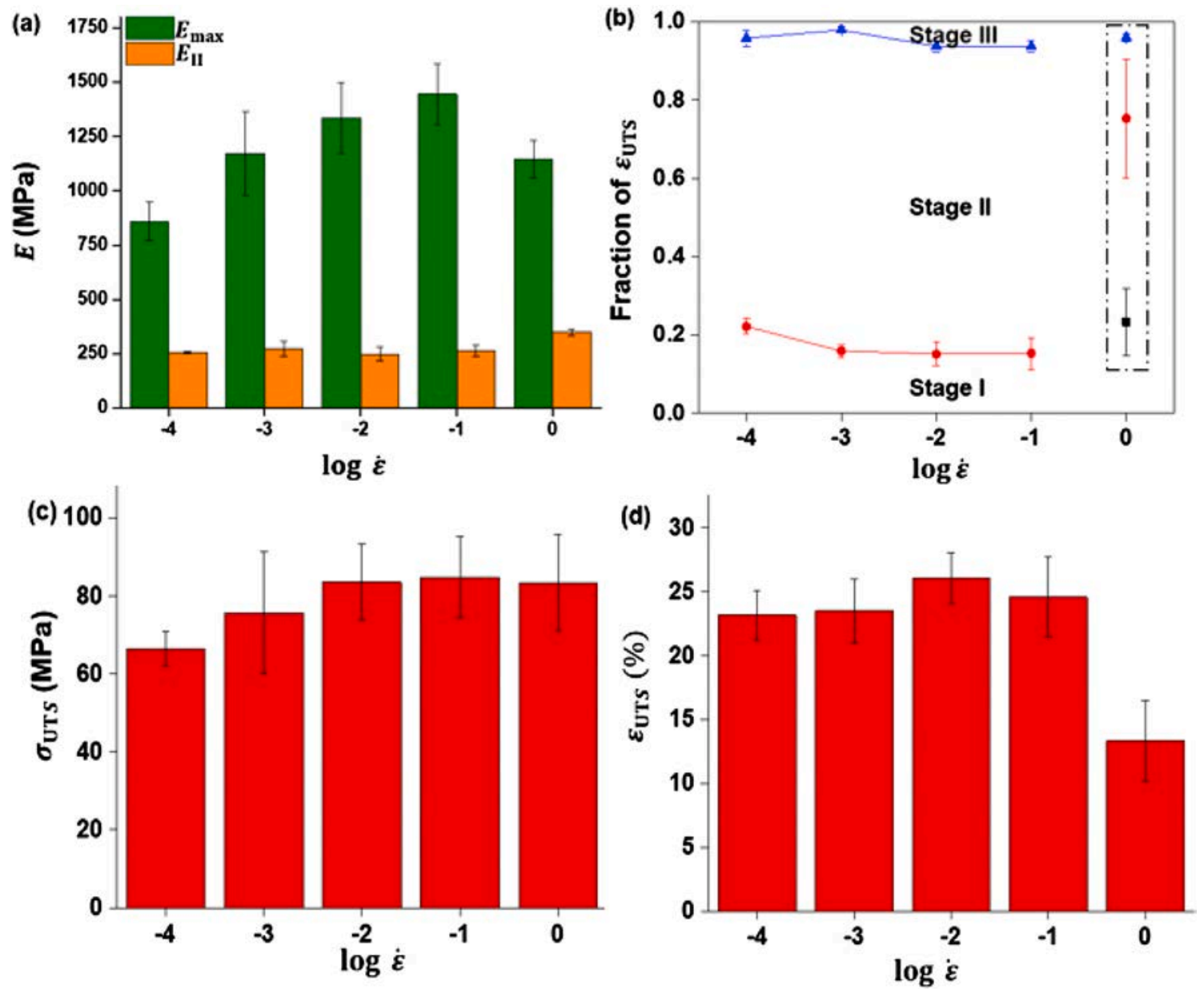

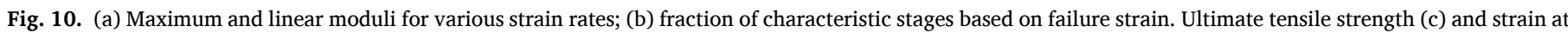
failure (d) at various strain rates.

$\left(\varepsilon_{\text {UTS }}\right)$ increased with transition from quasi-static $\left(0.0001 \mathrm{~s}^{-1}\right)$ strain-rate to intermediate $\left(0.01 \mathrm{~s}^{-1}\right)$ one and then decreased in dynamic loading $\left(1 \mathrm{~s}^{-1}\right)$ as presented in Fig. 10d (also observed in collagenous tissues (Pissarenko et al., 2019; Bonner et al., 2015)). The deformation of fibrillar structures leading to disruption of the matrix-fibril bonds (Karunaratne et al., 2018) might have caused a drop in strain at failure (for $1 \mathrm{~s}^{-1}$ ). All the values for Fig. 10 are presented in Table 5 .

\subsubsection{Strain-rate sensitivity exponent}

The strain-rate dependent behaviour of a material can be characterised using the strain-rate sensitivity exponent $m$. For a given tensile strain $\varepsilon$, the stress $\sigma$ may be presented as (Hertzberg, 1996):

$\sigma=\frac{F}{A}=K \dot{\varepsilon}^{m}$,

where $F$ is the force applied, $A$ is the cross-sectional area of the sample under load, $K$ is the material constant and $\dot{\varepsilon}$ is the strain rate. The sensitivity exponent, $m$, can be calculated from a log-log plot of the stresses to strain-rate at fixed strain, assessed with the following expression (Luo et al., 2010):

$m=\left.\frac{\Delta \log \sigma}{\Delta \log \dot{\varepsilon}}\right|_{\varepsilon}$.

The values of $m$ for the studied collagen film was calculated at each strain based on Eq. (2) for strain levels of 5, 10, 15 and 20\% (Fig. 11b). The same approach was used to predict the value of $m$ in biomaterials (Gao et al., 2016; Zhao et al., 2017).

Levels of stresses at a fixed strain value for various strain rates (Fig. 11a) increased with the growing strain rate, denoting a strainhardening behaviour of the collagen For $\varepsilon_{0.20}$ at $1 \mathrm{~s}^{-1}$, no value was obtained since the collagen specimen failed before reaching the assigned strain levels $\left(\varepsilon_{\text {UTS }}\right.$ was $13.33 \% \pm 3.13 \%$, Table 5 ). The strain-ratesensitivity exponent $m$ plotted against the strain rate (Fig. 11b) demonstrated positive values between 0.02-0.2 throughout the analysed strain range without $m$ dropping below zero. In this case, the positive $m$ values denoted a consistent hardening behaviour, as opposed to other

Table 5

Mechanical parameters for various strain rates obtained for characteristic stages.

\begin{tabular}{|c|c|c|c|c|c|c|c|c|}
\hline Strain rate $(\dot{\boldsymbol{\varepsilon}})\left(\mathrm{s}^{-1}\right)$ & $\boldsymbol{E}_{\max }(\mathrm{MPa})$ & $\boldsymbol{E}_{\text {II }}(\mathrm{MPa})$ & $\varepsilon_{1}(\%)$ & $\varepsilon_{2}(\%)$ & $\varepsilon_{\text {UTS }}(\%)$ & $\sigma_{\text {UTS }}(\mathrm{MPa})$ & $\frac{\varepsilon_{1}}{\varepsilon_{\text {UTS }}}$ & $\frac{\varepsilon_{2}}{\varepsilon_{\text {UTS }}}$ \\
\hline 0.0001 & $858.4 \pm 87.4$ & $255.6 \pm 5$ & $5.11 \pm 0.2$ & $22.30 \pm 1.41$ & $23.20 \pm 1.93$ & $66.5 \pm 4.5$ & $0.22 \pm 0.02$ & $0.96 \pm 0.02$ \\
\hline 0.001 & $1172 \pm 193.3$ & $273.5 \pm 33.1$ & $4.8 \pm 0.5$ & $20.7 \pm 2.6$ & $23.5 \pm 2.5$ & $75.7 \pm 15.7$ & $0.16 \pm 0.02$ & $0.98 \pm 0.01$ \\
\hline 0.01 & $1334 \pm 163.2$ & $247.7 \pm 32.1$ & $4.02 \pm 0.61$ & $24.5 \pm 1.9$ & $26.1 \pm 1.9$ & $83.62 \pm 9.63$ & $0.15 \pm 0.03$ & $0.94 \pm 0.02$ \\
\hline 0.1 & $1444 \pm 141.2$ & $262.4 \pm 25.9$ & $3.5 \pm 0.8$ & $23.1 \pm 3.0$ & $24.6 \pm 3.1$ & $84.9 \pm 10.5$ & $0.15 \pm 0.04$ & $0.94 \pm 0.02$ \\
\hline 1 & $1145 \pm 86.5$ & $349.1 \pm 15.1$ & $9.64 \pm 0.9$ & $12.8 \pm 3.1$ & $13.3 \pm 3.1$ & $83.5 \pm 12.4$ & $0.75 \pm 0.15$ & $0.96 \pm 0.01$ \\
\hline
\end{tabular}



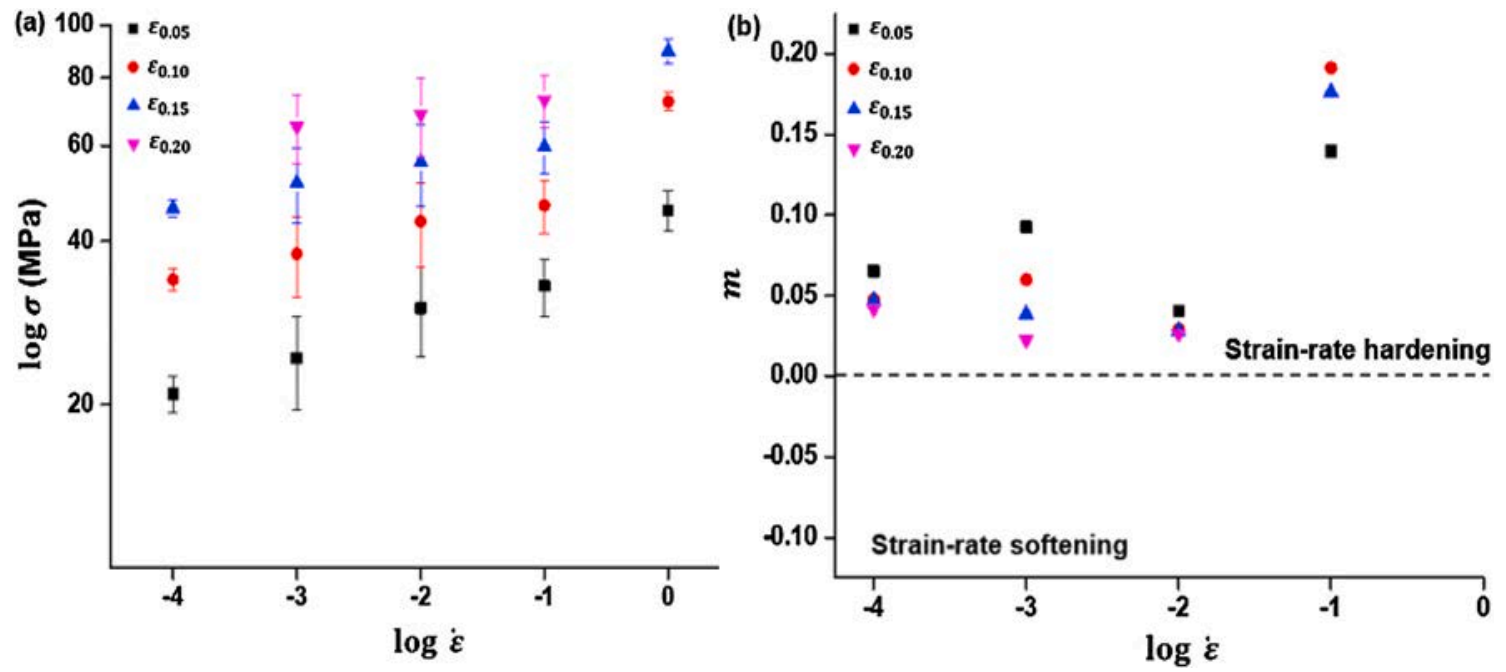

Fig. 11. (a) Stress vs. strain rate at corresponding strain; (b) effect of strain rate on strain-rate-sensitivity exponent plotted against strain rate.

biomaterials such as bacterial cellulose hydrogel where the $m$ values dropped to negative, exhibiting a strain-softening behaviour (Gao et al., 2016).

Apparently, at intermediate strain rate $\left(0.01 \mathrm{~s}^{-1}\right)$ the collagen was less sensitive to it, while in a dynamic loading regime, collagen was more strain-rate-sensitive. Since the value of $m$ approached zero at intermediate strain rate of $0.01 \mathrm{~s}^{-1}$, the common physiological loading rate of human (Schaffler et al., 1989), collagen might perform mostly as not strain-rate sensitive.

\section{Conclusions}

This paper investigated the effect of environmental conditions and strain rate on the mechanical response of collagen film. The samples were subjected to different environments to mimic conditions of potential biomedical applications. A wide range of strain rates was applied to the collagen films, ranging from quasi-static to intermediate to dynamic loading conditions demonstrating the effect of strain-rate sensitivity.

The obtained results for uncrosslinked collagen films subjected to different environmental conditions showed a drastic decrease in their mechanical strength and toughness - of more than $90 \%$ - of hydrated and submerged samples; however, their strain at failure increased by $75 \%$. The submerged samples exhibited an extension higher by $35 \%$ as compared to the hydrated ones, which was compensated by a drop in tensile strength of about $10 \%$. It was found that the effect of elevated temperature $\left(37^{\circ} \mathrm{C}\right)$ on mechanical properties of collagen samples was negligible. Evolution of the tangent modulus with strain for collagen films under dry and wet conditions exhibited totally different characteristic stages. This indicates that the presence of water molecules in collagen significantly changed its mechanical response, without significant differences between RT and PT. Thus, while characterising the mechanical behaviour of collagen-based materials or composites, the submerged (in-aqua) testing would be more suitable for applications in physiological conditions.

The values of material constants obtained for collagen in various environments with Abaqus software for hyperelastic models are suitable for future simulations to design collagen structures subjected to loading in-vivo. The Ogden model provided the best material constants for wet and submerged (in-aqua) collagen, which would provide realistic results.

Mechanical analysis of collagen at different strain rates demonstrated that collagen is strain-rate-sensitive. Its mechanical parameters such as tensile strength and modulus grew with the increase in the strain rate, indicating a strong rate-dependent hardening behaviour. Importantly, at dynamic strain rate of $1 \mathrm{~s}^{-1}$, the characteristic stages (obtained for the tangent modulus) were significantly different from those for other strain rates due to transient loading, which did not allow the stress transfer between collagen fibrils. The calculated strain-rate-sensitivity exponent was positive $(0.02-0.2)$ throughout the entire strain range for all the studied strain rates, further confirming a strain-ratedependent hardening behaviour of collagen. However, at intermediate strain rate for higher strain levels, the exponent was close to zero, implying low sensitivity of collagen to strain rate in most physiological activities.

\section{Author statement}

Shirsha Bose: Investigation; Data Curation; Writing- Original draft preparation; Simin Li: Conceptualization, Methodology; Writing- Original draft preparation; Elisa Mele: Conceptualization, Methodology; Writing- Original draft preparation; Vadim V. Silberschmidt: Conceptualization, Methodology; Writing- Original draft preparation; Supervision.

\section{Declaration of competing interest}

The authors declare that they have no known competing financial interests or personal relationships that could have appeared to influence the work reported in this paper.

\section{Acknowledgements}

The authors would like to acknowledge the support of Loughborough Materials Characterisation Centre (LMCC), Loughborough University, UK.

\section{References}

Ackerman, M.S., Bhate, M., Shenoy, N., Beck, K., Ramshaw, J.A.M., Brodsky, B., 1999. Sequence dependence of the folding of collagen-like peptides. J. Biol. Chem. 274 (12), 7668-7673. https://doi.org/10.1074/jbc.274.12.7668.

Andrews, M.E., Murali, J., Muralidharan, C., Madhulata, W., Jayakumar, R., 2003. Interaction of collagen with corilagin. Colloid Polym. Sci. 281 (8), 766-770. https:// doi.org/10.1007/s00396-002-0843-4.

Ber, S., Torun Köse, G., Hasirci, V., 2005. Bone tissue engineering on patterned collagen films: an in vitro study. Biomaterials 26 (14), 1977-1986. https://doi.org/10.1016/ j.biomaterials.2004.07.007.

Bonner, T.J., Newell, N., Karunaratne, A., Pullen, A.D., Amis, A.A., Bull, A.M.J., Masouros, S.D., 2015. Strain-rate sensitivity of the lateral collateral ligament of the 
knee. J. Mech. Behav. Biomed. Mater. 41, 261-270. https://doi.org/10.1016/j. jmbbm.2014.07.004.

Bose, S., Li, S., Mele, E., Silberschmidt, V.V., 2020. Dry vs. wet: properties and performance of collagen films. Part II. Cyclic and time-dependent behaviours. J. Mech. Behav. Biomed. Mater. (this issue).

Buehler, M.J., 2006. Nature designs tough collagen: explaining the nanostructure of collagen fibrils. Proc. Natl. Acad. Sci. Unit. States Am. 103 (33), 12285-12290. https://doi.org/10.1073/pnas.0603216103.

Clemmer, J., Liao, J., Davis, D., Horstemeyer, M.F., Williams, L.N., 2010. A Mechanistic Study for Strain Rate Sensitivity of Rabbit Patellar Tendon, vol. 43, pp. 2785-2791. https://doi.org/10.1016/j.jbiomech.2010.06.009.

Collins, R.L.L., Christiansen, D., Zazanis, G.A., Silver, F.H., 1991. Use of collagen film as a dural substitute: preliminary animal studies. J. Biomed. Mater. Res. 25, 267-276. https://doi.org/10.1002/jbm.820250212.

Delgado, L.M., Fuller, K., Zeugolis, D.I., 2017. Collagen cross-linking: biophysical, biochemical, and biological response analysis. Tissue Eng. 23 (19-20), 1064-1077. https://doi.org/10.1089/ten.tea.2016.0415.

Denning, D., Paukshto, M.V., Habelitz, S., Rodriguez, B.J., 2014. Piezoelectric properties of aligned collagen membranes. J. Biomed. Mater. Res. B Appl. Biomater. 102 (2), 284-292. https://doi.org/10.1002/jbm.b.33006.

Ding, C., Zhang, M., Li, G., 2015. Preparation and Characterization of Collagen/ Hydroxypropyl Methylcellulose (HPMC ) Blend Film, vol. 119, pp. 194-201.

Edwards, J.H., Ingham, E., Herbert, A., 2019. Decellularisation affects the strain rate dependent and dynamic mechanical properties of a xenogeneic tendon intended for anterior cruciate ligament replacement. J. Mech. Behav. Biomed. Mater. 91, 18-23. https://doi.org/10.1016/j.jmbbm.2018.11.023.

Falini, G., Fermani, S., Foresti, E., Parma, B., Rubini, K., Sidoti, M.C., Roveri, N., 2004 Films of self-assembled purely helical type I collagen molecules. J. Mater. Chem. 14 (14), 2297-2302. https://doi.org/10.1039/b401393j.

Fratzl, P., Misof, K., Zizak, I., Rapp, G., Bernstorff, S., 1998. Fibrillar structure and mechanical properties of collagen. J. Struct. Biol. 122 (1-2), 119-122.

Fratzl, P., 2008. Collagen: structure and mechanics, an introduction. In: Fratzl, P. (Ed.), Collagen: Structure and Mechanics. Springer, Boston, pp. 1-13.

Fukada, E., Yasuda, I., 1964. Piezoelectric effects in collagen. Jpn. J. Appl. Phys. 3 (2), 117.

Gager, V., Le Duigou, A., Bourmaud, A., Pierre, F., Behlouli, K., Baley, C., 2019. Understanding the effect of moisture variation on the hygromechanical properties of porosity-controlled nonwoven biocomposites. Polym. Test. 78, 105944. https://doi. org/10.1016/j.polymertesting.2019.105944.

Gao, X., Shi, Z., Lau, A., Liu, C., Yang, G., Silberschmidt, V.V., 2016. Effect of microstructure on anomalous strain-rate-dependent behaviour of bacterial cellulose hydrogel. Mater. Sci. Eng. C 62, 130-136. https://doi.org/10.1016/j. msec.2016.01.042.

Gautieri, A., Vesentini, S., Redaelli, A., Buehler, M.J., 2011. Hierarchical structure and nanomechanics of collagen microfibrils from the atomistic scale up. Nano Lett. 11 (2), 757-766. https://doi.org/10.1021/nl103943u.

Gautieri, A., Pate, M.I., Vesentini, S., Redaelli, A., Buehler, M.J., 2012. Hydration and distance dependence of intermolecular shearing between collagen molecules in a model microfibril. J. Biomech. 45 (12), 2079-2083. https://doi.org/10.1016/j. jbiomech.2012.05.047.

Ghosh, S.K., Mandal, D., 2017. Sustainable energy generation from piezoelectric biomaterial for noninvasive physiological signal monitoring. ACS Sustain. Chem. Eng. 5 (10), 8836-8843. https://doi.org/10.1021/acssuschemeng.7b01617.

Gopinath, D., Ahmed, M.R., Gomathi, K., Chitra, K., Sehgal, P.K., Jayakumar, R., 2004. Dermal wound healing processes with curcumin incorporated collagen films. Biomaterials 25 (10), 1911-1917. https://doi.org/10.1016/S0142-9612(03)006252.

Grover, C.N., Gwynne, J.H., Pugh, N., Hamaia, S., Farndale, R.W., Best, S.M., Cameron, R.E., 2012. Crosslinking and composition influence the surface properties, mechanical stiffness and cell reactivity of collagen-based films. Acta Biomater. 8 (8), 3080-3090. https://doi.org/10.1016/j.actbio.2012.05.006.

Hertzberg, R.W., 1996. Deformation and Fracture Mechanics of Engineering Materials. Wiley.

Hulmes, D.J., Wess, T.J., Prockop, D.J., Fratzl, P., 1995. Radial packing, order, and disorder in collagen fibrils. Biophys. J. 68 (5), 1661-1670. https://doi.org/10.1016/ S0006-3495(95)80391-7.

Jeannin, T., Gabrion, X., Ramasso, E., Placet, V., 2019. About the fatigue endurance of unidirectional flax-epoxy composite laminates. Compos. B Eng. 165, 690-701. https://doi.org/10.1016/j.compositesb.2019.02.009.

Jurvelin, J.S., Buschmann, M.D., Hunziker, E.B., 2003. Mechanical anisotropy of the human knee articular cartilage in compression. Proc. IME H J. Eng. Med. 217 (3), 215-219. https://doi.org/10.1243/095441103765212712.

Kaczmarek, B., Sionkowska, A., Skopinska-Wisniewska, J., 2018. Influence of glycosaminoglycans on the properties of thin films based on chitosan/collagen blends. J. Mech. Behav. Biomed. Mater. 80, 189-193. https://doi.org/10.1016/j jmbbm.2018.02.006.

Kadler, K.E., Baldock, C., Bella, J., Boot-Handford, R.P., 2007. Collagens at a glance. J. Cell Sci. 120 (12), 1955-1958. https://doi.org/10.1242/jcs.03453.

Karunaratne, A., Li, S., Bull, A.M.J., 2018. Nano-scale mechanisms explain the stiffening and strengthening of ligament tissue with increasing strain rate. Sci. Rep. 8 (1), 1-9. https://doi.org/10.1038/s41598-018-21786-z.

Kiss, M.Z., Daniels, M.J., Varghese, T., 2009. Investigation of temperature-dependent viscoelastic properties of thermal lesions in ex vivo animal liver tissue. J. Biomech. 42 (8), 959-966. https://doi.org/10.1016/j.jbiomech.2009.03.002.

Li, S., Liu, W.C., Chang, Y.H., Liu, X., Chang, C.L., Lin, C., Chung, R.J., 2019. Preparation and in vivo investigation of oligomeric proanthocyanidins cross-linked collagen serving as synthesized tissue regeneration membrane. Mater. Sci. Eng. C 101

640-649. https://doi.org/10.1016/j.msec.2019.03.112.

Li, W., Guo, R., Lan, Y., Zhang, Y., Xue, W., Zhang, Y., 2014. Preparation and properties of cellulose nanocrystals reinforced collagen composite films. J. Biomed. Mater. Res. 102 (4), 1131-1139. https://doi.org/10.1002/jbm.a.34792.

Liu, T., Shi, L., Gu, Z., Dan, W., Dan, N., 2017. 'A novel combined polyphenol-aldehyde crosslinking of collagen film-applications in biomedical materials'. Int. J. Biol. Macromol. 101, 889-895. https://doi.org/10.1016/j.ijbiomac.2017.03.166.

Liu, Y., Ren, L., Yao, H., Wang, Y., 2012. Collagen films with suitable physical properties and biocompatibility for corneal tissue engineering prepared by ion leaching technique. Mater. Lett. 87, 1-4. https://doi.org/10.1016/j.matlet.2012.07.091.

Liu, Y., Ren, L., Long, K., Wang, L., Wang, Y., 2014. Preparation and characterization of a novel tobramycin-containing antibacterial collagen film for corneal tissue engineering. Acta Biomater. 10 (1), 289-299. https://doi.org/10.1016/j. actbio.2013.08.033.

Liu, Y., Lv, H., Ren, L., Xue, G., Wang, Y., 2016. Improving the moisturizing properties of collagen film by surface grafting of chondroitin sulfate for corneal tissue engineering. J. Biomater. Sci. Polym. Ed. 27 (8), 758-772. https://doi.org/10.1080/ 09205063.2016.1160561.

Luo, J., Li, M., Yu, W., Li, H., 2010. The variation of strain rate sensitivity exponent and strain hardening exponent in isothermal compression of Ti-6Al-4V alloy. Mater. Des. 31 (2), 741-748. https://doi.org/10.1016/j.matdes.2009.09.055.

Lynch, H.A., Johannessen, W., Wu, J.P., Jawa, A., Elliott, D.M., 2003. Effect of fiber orientation and strain rate on the nonlinear uniaxial tensile material properties of tendon. J. Biomech. Eng. 125 (5), 726-731. https://doi.org/10.1115/1.1614819.

Maeda, M., Kadota, K., Kajihara, M., Sano, A., Fujioka, K., 2001. Sustained release of human growth hormone (hGH) from collagen film and evaluation of effect on wound healing in db/db mice. J. Contr. Release 77 (3), 261-272. https://doi.org/10.1016/ S0168-3659(01)00512-0.

Moeller, H.D., Bosch, U., Decker, B., 1995. Collagen fibril diameter distribution in patellar tendon autografts after posterior cruciate ligament reconstruction in sheep: changes over time. J. Anat. 187 (Pt. 1), 161-167.

Mooney, M., 1940. A theory of large elastic deformation. J. Appl. Phys. 11 (9), 582-592. https://doi.org/10.1063/1.1712836.

Moreno, S., Baniasadi, M., Mohammed, S., Mejia, I., Chen, Y., Quevedo-Lopez, M.A., Kumar, N., Dimitrijevich, S., Minary-Jolandan, M., 2015. Biocompatible collagen films as substrates for flexible implantable electronics. Adv. Electro. Mater. 1 (9), 1500154. https://doi.org/10.1002/aelm.201500154.

Nimni, M.E., Bernick, S., Cheung, D.T., Ertl, D.C., Nishimoto, S.K., Paule, W.J., Salka, C., Strates, B.S., 1988. Biochemical differences between dystrophic calcification of cross-linked collagen implants and mineralization during bone induction. Calcif. Tissue Int. 42 (5), 313-320. https://doi.org/10.1007/bf02556366.

Ogden, R.W., 1972. Large deformation isotropic elasticity - on the correlation of theory and experiment for incompressible rubberlike solids. Proc. Math. Phys. Eng. Sci. 328 (1575), 567-583. https://doi.org/10.5254/1.3542910.

Orgel, J.P.R.O., Irving, T.C., Miller, A., Wess, T.J., 2006. Microfibrillar structure of type I collagen in situ. Proc. Natl. Acad. Sci. Unit. States Am. 103 (24), 9001-9005. https:// doi.org/10.1073/pnas.0502718103.

Ottenio, M., Tran, D., Ní Annaidh, A., Gilchrist, M.D., Bruyère, K., 2015. Strain rate and anisotropy effects on the tensile failure characteristics of human skin. J. Mech. Behav. Biomed. Mater. 41, 241-250. https://doi.org/10.1016/j. jmbbm.2014.10.006.

Petruska, J.A., Hodge, A.J., 1964. A subunit model for the tropocollagen macromolecule. Proc. Natl. Acad. Sci. Unit. States Am. 51 (5), 871-876. Available at: http://www. pnas.org/content/51/5/871.

Pissarenko, A., Yang, W., Quan, H., Brown, K.A., Williams, A., Proud, W.G., Meyers, M. A., 2019. Tensile behavior and structural characterization of pig dermis. Acta Biomater. 86, 77-95. https://doi.org/10.1016/j.actbio.2019.01.023.

Sang, J., Li, X., Shao, Y., Li, Z., Fu, J., 2017. Controlled tubular unit formation from collagen film for modular tissue engineering. ACS Biomater. Sci. Eng. 3 (11), 2860-2868. https://doi.org/10.1021/acsbiomaterials.6b00468.

Schaffler, M.B., Radin, E.L., Burr, D.B., 1989. Mechanical and morphological effects of strain rate on fatigue of compact bone. Bone 10 (3), 207-214.

Sherman, V.R., Yang, W., Meyers, M.A., 2015. The materials science of collagen. J. Mech. Behav. Biomed. Mater. 52, 22-50. https://doi.org/10.1016/j.jmbbm.2015.05.023.

Shi, D., Liu, F., Yu, Z., Chang, B., Goff, H.D., Zhong, F., 2019. Effect of aging treatment on the physicochemical properties of collagen films. Food Hydrocolloids 87, 436-447. https://doi.org/10.1016/j.foodhyd.2018.08.016.

Sionkowska, A., Wisniewski, M., Skopinska, J., Poggi, G.F., Marsano, E., Maxwell, C.A., Wess, T.J., 2006. Thermal and mechanical properties of UV irradiated collagen/ chitosan thin films. Polym. Degrad. Stabil. 91 (12), 3026-3032. https://doi.org/ 10.1016/j.polymdegradstab.2006.08.009.

Sionkowska, A., Skopinska-Wisniewska, J., Gawron, M., Kozlowska, J., Planecka, A., 2010. Chemical and thermal cross-linking of collagen and elastin hydrolysates. Int. J. Biol. Macromol. 47 (4), 570-577. https://doi.org/10.1016/j.ijbiomac.2010.08.004.

Steele, T.W.J., Huang, C.L., Nguyen, E., Sarig, U., Kumar, S., Widjaja, E., Loo, J.S.C., Machluf, M., Boey, F., Vukadinovic, Z., Hilfiker, A., Venkatraman, S.S., 2013. Collagen-cellulose composite thin films that mimic soft-tissue and allow stem-cell orientation. J. Mater. Sci. Mater. Med. 24 (8), 2013-2027. https://doi.org/10.1007/ s10856-013-4940-3.

Tanaka, S., Avigad, G., Brodsky, B., Eikenberry, E.F., 1988. Glycation induces expansion of the molecular packing of collagen. J. Mol. Biol. 203 (2), 495-505. https://doi.org/ 10.1016/0022-2836(88)90015-0.

Torres, F.G., Troncoso, O.P., Montes, M.R., 2013. The effect of temperature on the mechanical properties of a protein-based biopolymer network. J. Therm. Anal. Calorim. 111 (3), 1921-1925. https://doi.org/10.1007/s10973-012-2915-0. 
Vrana, N.E., Elsheikh, A., Builles, N., Damour, O., Hasirci, V., 2007. Effect of human corneal keratocytes and retinal pigment epithelial cells on the mechanical properties of micropatterned collagen films. Biomaterials 28 (29), 4303-4310. https://doi.org/ 10.1016/j.biomaterials.2007.06.013.

Wang, W., Zhang, Y., Ye, R., Ni, Y., 2015. Physical crosslinkings of edible collagen casing. Int. J. Biol. Macromol. 81, 920-925. https://doi.org/10.1016/j. ijbiomac.2015.09.032

Wu, X., Liu, A., Wang, W., Ye, R., 2018. Improved mechanical properties and thermalstability of collagen fiber based film by crosslinking with casein, keratin or SPI: effect of crosslinking process and concentrations of proteins. Int. J. Biol. Macromol. 109, 1319-1328. https://doi.org/10.1016/j.ijbiomac.2017.11.144.

Yang, W., Sherman, V.R., Gludovatz, B., Schaible, E., Stewart, P., Ritchie, R.O., Meyers, M.A., 2015. On the tear resistance of skin. Nat. Commun. 6, 1-10. https:// doi.org/10.1038/ncomms7649.
Yeoh, O.H., 1993. Some forms of the strain energy function of rubber. Rubber Chem. Technol. 66 (5), 754-771.

Yuan, Y., Verma, R., 2006. Measuring microelastic properties of stratum corneum. Colloids Surf. B Biointerfaces 48 (1), 6-12. https://doi.org/10.1016/j. colsurfb. 2005.12.013.

Zhao, W., Li, X., Gao, S., Feng, Y., Huang, J., 2017. Understanding mechanical characteristics of cellulose nanocrystals reinforced PHEMA nanocomposite hydrogel: in aqueous cyclic test. Cellulose 24 (5), 2095-2110. https://doi.org/10.1007/ s10570-017-1244-7.

Zhou, C., Guo, H., Li, J., Huang, S., Li, H., Meng, Y., Yu, D., De Claville Christiansen, J., Jiang, S., 2016. Temperature dependence of poly(lactic acid) mechanical properties. RSC Adv. 6 (114), 113762-113772. https://doi.org/10.1039/c6ra23610c. 